\title{
Changes in environment over the last 800,000 years from chemical analysis of the EPICA Dome $C$ ice core
}

\author{
E.W. Wolff ${ }^{\mathrm{a}, *}$, C. Barbante ${ }^{\mathrm{i}}$, S. Becagli ${ }^{\mathrm{g}}$, M. Bigler ${ }^{\mathrm{e}, \mathrm{f}}$, C.F. Boutron ${ }^{\mathrm{c}}$, E. Castellano ${ }^{\mathrm{g}}$, M. de Angelis ${ }^{\mathrm{c}}$, \\ U. Federer $^{\mathrm{e}}$, H. Fischer ${ }^{\mathrm{b}, \mathrm{e}, \mathrm{j}}$, F. Fundel $^{\mathrm{b}}{ }^{\text {, M. Hansson }}{ }^{\mathrm{d}}$, M. Hutterli ${ }^{\mathrm{a}}$, U. Jonsell ${ }^{\mathrm{d}}$, T. Karlin ${ }^{\mathrm{d}}$, P. Kaufmann ${ }^{\mathrm{e}}$, \\ F. Lambert ${ }^{\mathrm{e}}$, G.C. Littot $^{\mathrm{a}}{ }^{\text {, R. Mulvaney }}{ }^{\mathrm{a}}$, R. Röthlisberger ${ }^{\mathrm{a}}$, U. Ruth ${ }^{\mathrm{b}}$, M. Severi ${ }^{\mathrm{g}}$, M.L. Siggaard-Andersen ${ }^{\mathrm{f}}$, \\ L.C. Sime ${ }^{\text {a }}$, J.P. Steffensen ${ }^{\text {f, T.F. Stocker }}{ }^{\text {e }}$, R. Traversi ${ }^{g}$, B. Twarloh ${ }^{b}$, R. Udisti $^{g}$, D. Wagenbach $^{\text {h }}$, A. Wegner $^{\text {b }}$ \\ ${ }^{a}$ British Antarctic Survey, High Cross, Madingley Road, Cambridge, CB3 OET, UK \\ ${ }^{\mathrm{b}}$ Alfred Wegener Institute for Polar and Marine Research, Columbusstrasse, D-27568 Bremerhaven, Germany \\ ${ }^{\mathrm{c}}$ Laboratoire de Glaciologie et Géophysique de l'Environnement, BP96, 38402 St. Martin d'Hères Cedex, France \\ ${ }^{\mathrm{d}}$ Department of Physical Geography and Quaternary Geology, Stockholm University, 10691 Stockholm, Sweden \\ e Climate and Environmental Physics, Physics Institute, University of Bern, Sidlerstrasse 5, CH-3012 Bern, Switzerland \\ ${ }^{\mathrm{f}}$ Department of Geophysics, Juliane Maries Vej 30, University of Copenhagen, DK-2100 Copenhagen Ø, Denmark \\ ${ }^{\mathrm{g}}$ Department of Chemistry - Analytical Chemistry Section, Scientific Pole - University of Florence, Via della Lastruccia 3, 50019 Sesto Fiorentino (Florence), Italy \\ ${ }^{\mathrm{h}}$ Institut für Umweltphysik, University of Heidelberg, INF 229, 69120 Heidelberg, Germany \\ ${ }^{\mathrm{i}}$ Environmental Sciences Department, University of Venice, Calle Larga S. Marta, 2137, I-30123 Venice, Italy \\ ${ }^{\mathrm{j}}$ Oeschger Centre for Climate Change Research, University of Bern, 3012 Bern, Switzerland
}

\section{A R T I C L E I N F O}

\section{Article history:}

Received 10 February 2009

Received in revised form

16 June 2009

Accepted 16 June 2009

\begin{abstract}
A B S T R A C T
The EPICA ice core from Dome C extends $3259 \mathrm{~m}$ in depth, and encompasses $800 \mathrm{ka}$ of datable and sequential ice. Numerous chemical species have been measured along the length of the cores. Here we concentrate on interpreting the main low-resolution patterns of major ions. We extend the published record for non-sea-salt calcium, sea-salt sodium and non-sea-salt sulfate flux to $800 \mathrm{ka}$. The non-sea-salt calcium record confirms that terrestrial dust originating from South America closely mirrored Antarctic climate, both at orbital and millennial timescales. A major cause of the main trends is most likely climate in southern South America, which could be sensitive to subtle changes in atmospheric circulation. Seasalt sodium also follows temperature, but with a threshold at low temperature. We re-examine the use of sodium as a sea ice proxy, concluding that it is probably reflecting extent, with high salt concentrations reflecting larger ice extents. With this interpretation, the sodium flux record indicates low ice extent operating as an amplifier in warm interglacials. Non-sea-salt sulfate flux is almost constant along the core, confirming the lack of change in marine productivity (for sulfur-producing organisms) in the areas of the Southern Ocean contributing to the flux at Dome C. For the first time we also present long records of reversible species such as nitrate and chloride, and show that the pattern of post-depositional losses described for shallower ice is maintained in older ice. It appears possible to use these concentrations to constrain snow accumulation rates in interglacial ice at this site, and the results suggest a possible correction to accumulation rates in one early interglacial. Taken together the chemistry records offer a number of constraints on the way the Earth system combined to give the major climate fluctuations of the late Quaternary period.
\end{abstract}

(c) 2009 Elsevier Ltd. All rights reserved.

\section{Introduction}

The climate of the late Quaternary is dominated by the huge glacial-interglacial swings occurring at orbital timescales (Lisiecki and Raymo, 2005; Jouzel et al., 2007), and secondarily by related

\footnotetext{
* Corresponding author. Tel.: +44 1223 221491; fax: +44 1223221279

E-mail address: ewwo@bas.ac.uk (E.W. Wolff).
}

changes in both hemispheres at millennial scale (e.g. EPICA Community Members, 2006). These changes have particularly been highlighted by data from the long Antarctic ice cores, showing the dominance of these patterns in Antarctic temperature (Watanabe et al., 2003a; Jouzel et al., 2007), and in greenhouse gas concentrations (Loulergue et al., 2008; Lüthi et al., 2008). The causes of the climatic and biogeochemical changes are complex, involving an interplay between external forcings and internal feedbacks and amplifiers. Unravelling the mechanisms at work requires 
knowledge of other important parts of the Earth system, such as sea ice extent, aerosol load, and biological productivity of the ocean.

Ice cores can play a further role in such studies, because they can reveal other aspects of Earth system change, through the varying deposition of trace chemicals trapped in the snow (as opposed to the trace gases trapped in air bubbles). Such records are difficult to interpret, because they concern mainly short-lived aerosol and gasphase species, and result from a combination of changes in source strength, transport, deposition and (in some cases) preservation. Nevertheless they certainly contain a wealth of information about important environmental parameters (Legrand and Mayewski, 1997).

Records of some of the major ions in ice covering one or more climatic cycles have previously been presented from the Vostok (Legrand et al., 1988; Petit et al., 1999) and Dome Fuji (Watanabe et al., 2003b) ice cores. More recently data on material from oceanic and terrestrial sources have been shown to an age of $740 \mathrm{ka}$ (Wolff et al., 2006) from the EPICA Dome C ice core. Millennial scale variability in dust and sea salt components has also been discussed, using data from two different EPICA sites over one glacial cycle (Fischer et al., 2007). Here we extend the Dome C record to its full length of 800 ka for non-sea-salt calcium (related to terrestrial dust), sea salt sodium (representing sea salt), and non-sea-salt sulfate. We re-examine the interpretation of these data, referring in some cases to other papers in this volume that discuss these issues in more detail, and we summarise the findings from the long datasets. For two other major ions (nitrate and chloride), data have previously been presented from Dome C only for the last $45 \mathrm{ka}$ (Röthlisberger et al., 2000b; Röthlisberger et al., 2003; Udisti et al., 2005); their concentrations appeared to be strongly controlled by changes in the extent to which they are preserved in ice under different climatic conditions. Here we extend those records to $800 \mathrm{ka}$, and consider whether the tentative interpretations of the recent period hold over the entire profile; based on this we consider how they might be useful for confirming aspects of the ice core age model. Finally we discuss how the different aspects of the system uncovered by ice core studies can be used together to elucidate the mechanisms of climate change.

\section{Impurities in Antarctic ice}

The impurities found in Antarctic snow and ice are mainly brought to the continent as aerosol, although some material (for example nitric and hydrochloric acid) may also be partly deposited directly from the gas-phase. The main classes of material that can be found and measured in the ice are:

(a) Terrestrial material derived from soils and mineral dust. This can be investigated by looking at insoluble dust particle numbers, size and volume (Delmonte et al., 2004; Lambert et al., 2008), or by a range of elemental markers (Ruth et al., 2008), such as Al, Fe or Ca. In this paper, we use calcium, after making a correction for sea salt input of the element. Because the composition of the dust arriving in Antarctica may vary with time, no single element can give a holistic picture of the input of terrestrial material; however, it appears that the gross changes are represented by each marker that has been used. It has previously been shown through a range of geochemical studies that the main source of dust to Antarctica is southern South America (Delmonte et al., 2008), although it is possible that other sources contribute during interglacials.

(b) Primary marine aerosol, derived ultimately from seawater. In this paper, we use $\mathrm{Na}$ (after a correction, to be discussed later, for terrestrial material) as the indicator for this aerosol. Other major cations found in seawater, such as $\mathrm{Mg}$, $\mathrm{K}$, and $\mathrm{Ca}$, have a greater relative proportion of their input from terrestrial material, and therefore a mixed interpretation. At central Antarctic sites, chloride, often used as a marine indicator elsewhere, suffers from strong changes due to reactions with acid (Legrand et al., 1996; Röthlisberger et al., 2003), and the loss or addition of $\mathrm{HCl}$, as discussed later, and is therefore unsuitable as a quantitative indicator of marine input. Secondary organic marine aerosol has not yet been much-considered in ice core studies, but has a potential for future study. Secondary marine aerosol derived from $\mathrm{S}$ compounds is discussed in the next paragraph.

(c) Biogenic sulfur species. Both methanesulfonate (often abbreviated in its acidic form as MSA) and sulfate in central Antarctica derive largely from the oxidation of dimethylsulfide (DMS), produced by marine algae. In coastal regions, MSA is preferred, because it has no other known sources, whereas some sulfate also derives from sea salt, volcanism, terrestrial material, and pollution. However, MSA is poorly preserved in interglacial ice in central Antarctica (e.g. Wagnon et al., 1999; Weller et al., 2004), and can therefore not be used to track marine biogenic changes (Wolff et al., 2006). Fortunately, on the East Antarctic plateau, the sea salt correction for sulfate is generally small and easily made and the other sources relatively minor; we therefore use sulfate, after making the sea salt correction, as a marker of the marine biogenic input to central Antarctica. It has also been proposed that ammonium can act as a marine biogenic marker, and this is explored in another paper in this volume (Kaufmann et al, 2010).

(d) Volcanic material. Large volcanic eruptions from which $\mathrm{SO}_{2}$ reaches the stratosphere, leave a signature of spikes of sulfate, lasting up to a few years, that dominate the short term variability of sulfate (Castellano et al., 2004) and electrical conductivity records in polar ice. Volcanic material certainly contributes to background concentrations of many trace elements, although its input is particularly highlighted in very occasional visible ash layers that contain particularly high levels of impurity (Basile et al., 2001).

(e) Acidic gases. Nitrate and chloride can both be deposited as salts in the aerosol phase, and as acids from the gas-phase. The origin of nitrate in the Antarctic atmosphere is not completely understood, but is likely a combination of input from the stratosphere, from low latitude sources, and recycling from elsewhere in the continent through photolysis and evaporation/condensation processes (Savarino et al., 2007; Wolff et al., 2008). Chloride derives from sea salt, with the acidic component resulting from reactions of sea salt aerosol with sulphuric or nitric acid. The amount of nitric and hydrochloric acid (as well as organic acids) actually preserved in ice seems to be strongly dependent on conditions in the ice (snow accumulation rate, temperature, concentrations of other impurities) (Röthlisberger et al., 2000b; Röthlisberger et al., 2003).

(f) Other material. There has been little study of more exotic materials in the ice. Recent work has investigated the tiny amounts of extraterrestrial material (Gabrielli et al., 2006; Winckler and Fischer, 2006). Cosmogenically-derived material, such as ${ }^{10} \mathrm{Be}$, also forms part of the chemical content of ice, and has been of significant use in synchronising and dating ice cores (e.g. Raisbeck et al., 2006). Until now very few studies of organic or biological material have been made in Antarctic ice, and none have surveyed through climatic cycles.

In this paper, we will discuss markers representing the classes a, b, c and e described above over the 800 ka period of the Dome $C$ ice core. 


\section{Methods}

The data in this paper come from the ice core, drilled by the European Project for Ice Coring in Antarctica (EPICA), from Dome $C$ $\left(75^{\circ} 06^{\prime} \mathrm{S}, 123^{\circ} 21^{\prime} \mathrm{E}\right.$, altitude $3233 \mathrm{~m}$ above sea level). This site is far removed from any terrestrial or marine sources, and therefore represents input of material to the central East Antarctic plateau from outside the continent.

Samples from 0 to $580 \mathrm{~m}$ depth were prepared by cutting discrete samples from a section of the core, removing contaminated outer layers with a plane or scalpel, and melting the ice. Below $580 \mathrm{~m}$, samples were collected into sample vials using a melting device: a $3.4 \times 3.4 \mathrm{~cm}$ strip of ice was melted onto a hotplate (either in the field or in a European cold laboratory) (Röthlisberger et al., 2000a; Kaufmann et al., 2008), and part of the melt from the inner part of the core was fed into vials for later ion chromatography (IC) analysis; along the entire core another part of the melt was led directly to various detection devices (in a continuous flow analysis (CFA) system). Of the components shown here, $\mathrm{Na}^{+}, \mathrm{NO}_{3}^{-}$and $\mathrm{Ca}^{2+}$ were determined both by IC from the vials, and spectrometrically using the CFA system (Röthlisberger et al., 2000a; Kaufmann et al., 2008). The results shown here are from IC, but good agreement between methods is generally found (Littot et al., 2002). The exception is for $\mathrm{Ca}^{2+}$ in the upper $580 \mathrm{~m}$, for which the IC data may be slightly contaminated due to possible incomplete removal of outer layers. This problem does not affect any other ions; beyond $580 \mathrm{~m}$, we found generally good agreement between IC and CFA $\mathrm{Ca}^{2+}$ data, although CFA concentrations tended to be slightly lower than those measured by IC at the lowest concentrations found in interglacial periods. We have therefore used the CFA $\mathrm{Ca}^{2+}$ data for the upper $580 \mathrm{~m}(27 \mathrm{ka})$. The anions presented here were measured by passing some of the CFA water directly into a fast IC (FIC) device (Traversi et al., 2002), as well as by conventional IC. A comparison between the two methods shows excellent agreement, but hereafter IC data are used. None of the three methods described here is likely to measure the insoluble fraction of terrestrial dust (Ruth et al., 2008).

Major ions presented here $\left(\mathrm{Na}^{+}, \mathrm{Ca}^{2+}, \mathrm{Cl}^{-}, \mathrm{NO}_{3}^{-}, \mathrm{SO}_{4}^{2-}\right)$ were measured in 6 different laboratories by IC; the estimated uncertainty on individual measurements is better than $5 \%$ at higher concentrations (Littot et al., 2002), increasing somewhat close to detection limits (e.g. interglacial Ca values). Below $2162 \mathrm{~m}$ ( $\sim 200 \mathrm{ka}$ ), we have used a set of samples, each integrating $0.55 \mathrm{~m}$ or $1.1 \mathrm{~m}$ of ice melt, analysed by a single laboratory, thus eliminating any inter-laboratory inconsistency. Above that depth, samples typically 5-11 cm long, were analysed in sections by different laboratories, and then averaged. Larger inter-laboratory differences than expected from the analytical uncertainty and inter-sample variability were observed for one or more ions in some depth intervals. As a result a small number of data blocks from particular laboratories were rejected; in these cases, averages using only data from the other laboratories were used. In particular: (1) for one ion $\left(\mathrm{Ca}^{2+}\right)$, one laboratory reported occasional high spikes in concentration in one period of analysis; the entire $\mathrm{Ca}^{2+}$ dataset for these analytical periods from that laboratory were rejected. (2) One laboratory had an outlying low sensitivity in a round robin sample intercomparison carried out at the end of one year of analysis; as a result the data from that laboratory for all ions analysed that year were removed from the dataset. (3) One laboratory showed consistently lower average values than the others for just one anion $\left(\mathrm{Cl}^{-}\right)$during one year of analyses; the $\mathrm{Cl}^{-}$values for that laboratory during that year of analysis have been removed from the dataset. This procedure for rejecting data ensured a consistent analytical procedure, but still gave sufficient time resolution at all depths for the studies in this paper. Higher resolution studies can be carried out using data from fewer ions measured by a single laboratory (Röthlisberger et al., 2008); or by carefully normalising the IC data from different laboratories.

The timescale is EDC3 (Parrenin et al., 2007), and the accumulation rates used to calculate flux also derive from EDC3. Because data published previously (Wolff et al., 2006; Wolff et al., 2007) were on the less-sophisticated EDC2 age scale, both the fluxes and age of samples shown here differ slightly in their common time period from earlier datasets, although the pattern of change remains the same.

We calculated sea-salt-Na (ssNa) and non-sea-salt-Ca (nssCa) assuming a $\mathrm{Ca} / \mathrm{Na}$ weight ratio of 0.038 for marine aerosols and 1.78 for the average crust (Bowen, 1979). While the latter figure could be highly variable between different terrestrial sources, leading to a substantial uncertainty in ssNa, many previous authors (Legrand and Delmas, 1988; Röthlisberger et al., 2002b) have suggested that this is the most suitable ratio to use. Some evidence suggests that the crustal source material may be dominated by marine clays or other Na-rich material, leading to a recommended ratio of $\mathrm{Ca} / \mathrm{Na}$ of 1.06, and a larger correction for terrestrial Na (Bigler et al., 2006). The reduced ratio gives an insignificant change to nssCa (and later, to $\mathrm{nsSO}_{4}^{2-}$ ); there is a noticeable difference for $\mathrm{ssNa}$ (which we show as a dashed line in Fig. 1). However, no reasonable ratios affect the general pattern of the derived time series, nor the conclusions of this paper, so for consistency with our earlier work we have used

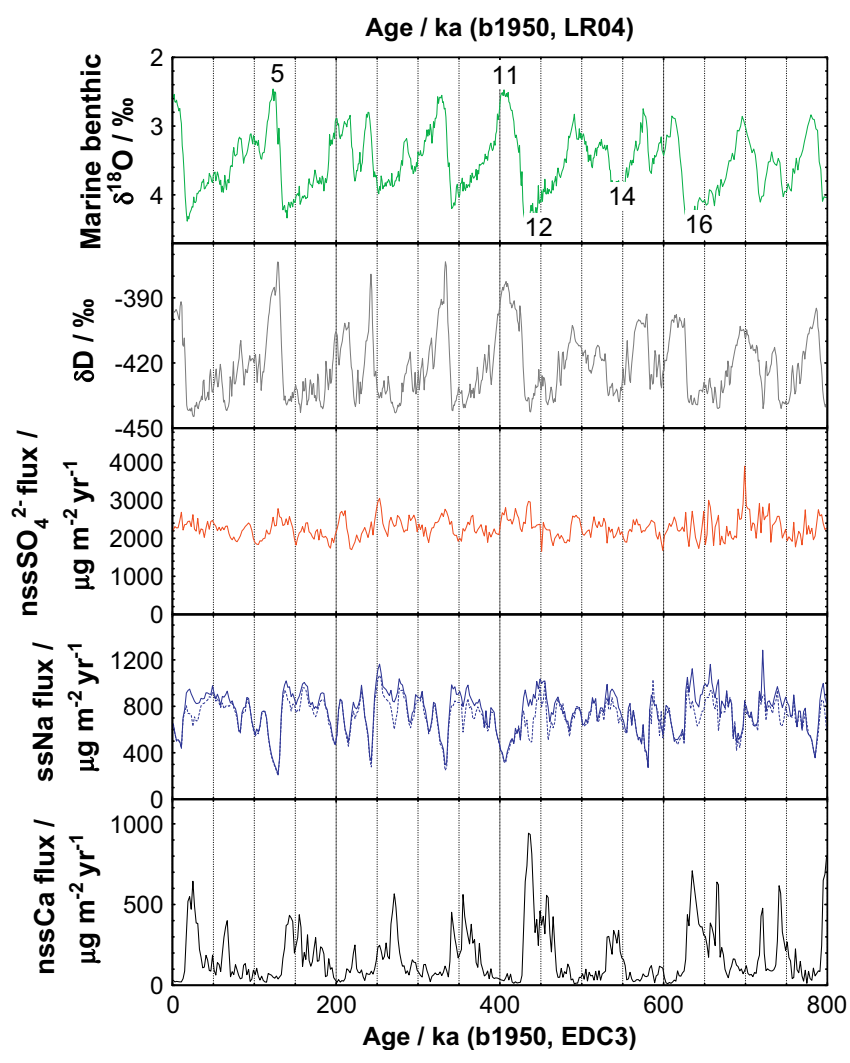

Fig. 1. Chemical fluxes to $800 \mathrm{ka}$ ago. Fluxes shown for nssCa, ssNa and nssSO ${ }_{4}^{2-}$ are $2 \mathrm{ka}$ averages. Calculations are shown using mean seawater and crustal ratios of $\mathrm{Na} / \mathrm{Ca}$, as discussed in the text. ssNa calculated using an alternative crustal ratio (Bigler et al., 2006) is shown as a dashed line. Deuterium (Antarctic temperature proxy) is also shown, as $1 \mathrm{ka}$ averages. All Dome C records are on the EDC3 age scale. A marine benthic isotope stack (Lisiecki and Raymo, 2005) is also shown for comparison, and is on the LR04 age scale. The notation (b1950) is used to indicate years before a reference of 1950 AD. 
the value of 1.78 . We confirm over the extended time period that, on average about $90 \%$ of $\mathrm{Na}$ is from sea salt, although the proportion occasionally falls below $70 \%$ in glacial periods (or even $50 \%$ with the larger terrestrial Na correction). About $90 \%$ of Ca in glacial times is from terrestrial sources, but the proportion can be much lower in interglacials.

Non-sea salt $\mathrm{SO}_{4}^{2-}\left(\mathrm{nssSO}_{4}^{2-}\right)$ was first derived by subtracting the sea salt part, traditionally calculated by using ssNa and applying the weight ratio of $\mathrm{SO}_{4}^{2-} / \mathrm{Na}$ in seawater $(0.25)$. However, if the main source of sea salt is actually the sea ice surface, then this source is depleted in sulfate compared to seawater, with a ratio close to 0.1 (Wagenbach et al., 1998; Rankin et al., 2002); there is now some direct evidence that material with a low ratio reaches the Dome $\mathrm{C}$ site (Jourdain et al., 2008). We present $\mathrm{nsSO}_{4}^{2-}$ fluxes calculated with the latter method - again our choice does not significantly affect the results of this paper. A small terrestrial input of sulfate might be present, especially in glacials, when the dust concentration is high. Sulfate/dust ratios in terrestrial aerosol are highly variable and source-dependent. We therefore refrain from making a dust correction of $\mathrm{nsSO}_{4}^{2-}$, but recognise that the glacial values might be upper limits.

For nitrate and chloride, where post-depositional effects dominate the observed profiles, we present concentrations as measured in meltwater from the ice. For the other ions we present fluxes, calculated using snow accumulation rates derived from deuterium values as part of the production of the EDC3 age scale (Parrenin et al., 2007). We use fluxes because their changes are more representative of atmospheric concentration changes if, as is generally believed for Dome C, dry deposition dominates over wet deposition of aerosol. This choice tends to reduce the glacial-interglacial contrasts compared to those observed with concentration, because snow accumulation rates are lower in glacial periods when ionic concentrations are higher. The data covering the entire $800 \mathrm{ka}$ period are presented as averages over 1 ka or 2 ka periods.

\section{Results}

Fig. 1 shows the flux of nssCa, ssNa and $\mathrm{nssSO}_{4}^{2-}$ at Dome $\mathrm{C}$ for the last $800 \mathrm{ka}$. Also shown are deuterium (Antarctic temperature proxy) (Jouzel et al., 2007), and a marine benthic ${ }^{18} \mathrm{O}$ record (Lisiecki and Raymo, 2005), obtained from a stack of cores, and representing a combination of global ice volume and deep water temperature. This record improves on data presented previously by using the new EDC3 age scale (which also changes derived snow accumulation rates and calculated fluxes), and by extending the records through marine isotope stages (MIS) 18 and 19, to the end of MIS20 at $800 \mathrm{ka}$ (b1950, where this notation implies time before a zero of $1950 \mathrm{AD}$ ).

All three ions show the same pattern we observed in the previous reduced dataset. $\mathrm{NssSO}_{4}^{2-}$ flux has similar values throughout the dataset, again with no glacial-interglacial contrast across the MIS18/19/20 boundaries. SsNa flux continues to show glacial-interglacial contrasts of approximately factor 2, with lower values in warm periods, and relatively little variability during cold periods. The flux in MIS19 reaches values slightly lower than minimum values seen in the Holocene. NssCa flux shows huge (up to factor 20) glacial-interglacial contrast, with the highest values at the coldest periods. MIS19 exhibits low fluxes similar to those seen in other interglacials, while the deepest ice in MIS20 has values a little higher than are observed in most other glacials, exceeded only by values in MIS12.

Fig. 2 shows the concentrations of $\mathrm{NO}_{3}^{-}$and $\mathrm{Cl}^{-}$at Dome $\mathrm{C}$ for the last $800 \mathrm{ka}$. Also shown are the nssCa and ssNa concentration, and the deuterium values. Nitrate shows much higher concentrations in glacial periods, particularly when nssCa is high; typical

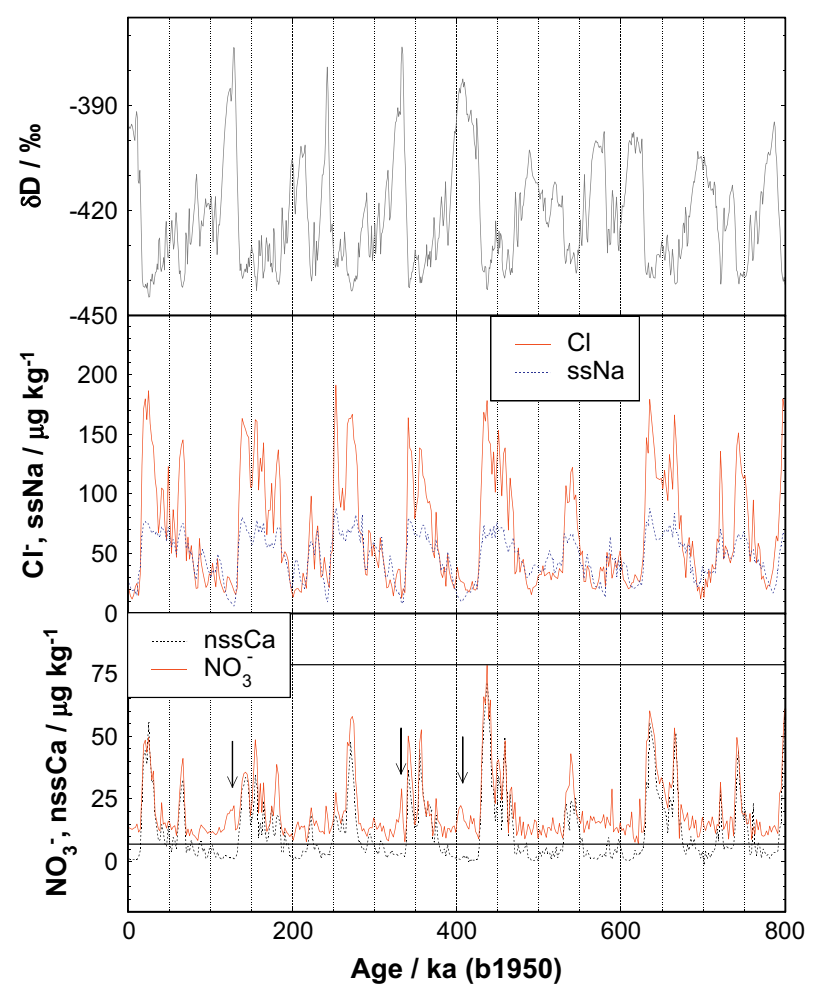

Fig. 2. Nitrate and chloride concentrations to $800 \mathrm{ka}$ ago. Concentrations shown are 2 ka averages; the concentration of nssCa and ssNa are also shown for comparison, as are values of Dome $\mathrm{C}$ deuterium ( 1 ka averages). Arrows above the $\mathrm{NO}_{3}-$ curve show examples of nitrate peaks that are independent of nssCa peaks.

glacial/interglacial ratios are around $5 . \mathrm{Cl}^{-}$shows a similar general structure to $\mathrm{Na}$, including the highest values occurring in glacial maxima, and always low concentrations in interglacials. However, the relative strength of $\mathrm{Cl}^{-}$and $\mathrm{Na}$ concentration in different climatic periods is different, and the ratio of $\mathrm{Cl}^{-} / \mathrm{Na}$ varies a lot, as we explore later.

\section{Discussion}

We now discuss in turn the different classes of chemicals described in Section 2, summarising our best understanding of the interpretations of the data shown in Section 4.

\subsection{Calcium as an indicator of terrestrial input}

Ca is taken as an indicator of input of terrestrial dust. However, we compare it in Fig. 3 with insoluble dust as recently presented (Lambert et al., 2008) based on optical measurements of dust particle size spectra integrated to give mass. Generally speaking the two profiles are congruent (with a ratio 20:1, i.e. suggesting that soluble nssCa is $5 \%$ of total dust mass). Compared to nssCa, dust gives a lower relative value for some interglacials, but notably relatively lower values for glacials beyond $600 \mathrm{ka}$. The result of this is that MIS 16, 18 and 20 appear to have low dust concentrations compared to MIS 8,10 and 12 , which is not the case if nssCa is considered. We are unable to say whether this difference is due to a change in the composition of aeolian dust in the earlier period, or a difficulty in measuring the correct concentration in deeper ice in one method or the other; until this can be resolved we must treat trends in the relative dustiness of glacials with some care.

We will not discuss in detail here aspects of the nssCa record that have already been discussed extensively, such as the relationship 


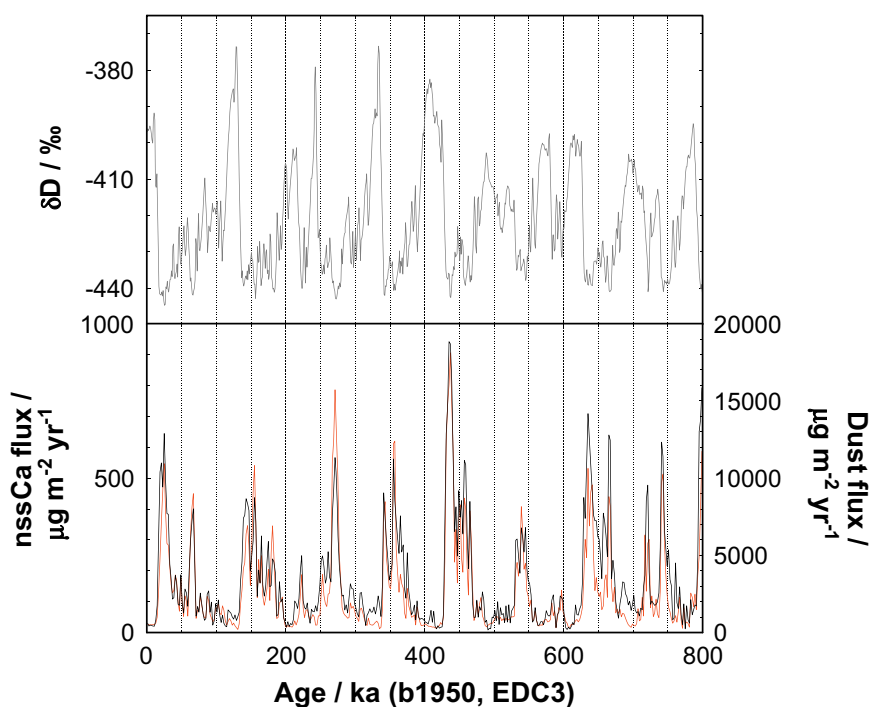

Fig. 3. NssCa (black) and dust (red) fluxes over the last $800 \mathrm{ka}$ at Dome C. Values are shown as $2 \mathrm{ka}$ averages. Deuterium is shown for comparison in the upper plot.

between dust proxies and temperature over long timescales (Lambert et al., 2008; Röthlisberger et al., 2008). The two most obvious features of the nssCa record, as noted previously (Wolff et al., 2006; Lambert et al., 2008) are (a) that the fluxes in different interglacials are rather similar, suggesting that there is a threshold in response of dust sources and transport relative to Antarctic temperature (Röthlisberger et al., 2010), and (b) that there is a huge contrast between glacial and interglacial fluxes, with peak glacial fluxes about a factor 20 higher than those seen in interglacials or in mild parts of glacials. It is well-established that the main source of dust to Antarctica during glacials is southern South America (Delmonte et al., 2008), even if other sources might be relevant during interglacials. Therefore the main issue is to explain a factor 20 increase in either the source or transport (or a combination) of South American dust to Antarctica.

There are three main classes of explanation for this increase, and here we make our own assessment of them. These are:

(a) Changes in the areal extent of the dust source, due to the increased area of continental shelf exposed during times of low sea level.

(b) Changes in the strength of transport from South America to Antarctic sites, or in the amount of deposition between South America and Antarctica; these two factors together alter the amount of dust reaching Antarctica. We do not consider here changes in deposition in Antarctica, because these are already accounted for by using the flux, making the assumption that dry deposition dominates.

(c) Changes in the source strength from South America resulting from changes in glacier extent, river routing, vegetation, precipitation or wind speed for uplift; these can all be considered together under the heading of changes in the climate of southern South America.

\subsubsection{Sea level and continental shelf area}

Limits can easily be placed on the possible role of (a) by considering the timing of change in dust flux and sea level during terminations and inceptions. We previously considered this for termination I (Röthlisberger et al., 2002b; Wolff et al., 2006), and expand on this explanation here.
When sea level falls, the Argentine continental shelf to the east of Patagonia becomes exposed. It has been estimated that, at the LGM, the net relative sea level (RSL) at this shelf, due to eustatic and hydroisostatic components with a small correction for tectonic uplift, was $150 \mathrm{~m}$ below present sea level (of which $-110 \mathrm{~m}$ was eustatic) (Guilderson et al., 2000). We previously illustrated (Wolff et al., 2006, Supplementary Fig. 2) the depth of the continental shelf, showing that $70 \%$ of the shelf area would flood by the time RSL reaches $-80 \mathrm{~m}$. However, combining the change in RSL (Guilderson et al., 2000) with the areas of shelf at each depth (Fig. 4) it is easy to see that most of the fall in nssCa flux occurs well before any significant change in continental shelf area. In particular, the flux of nssCa has halved by $17 \mathrm{ka}$, when the change in sea level, both in the Argentine continental shelf, and in other reconstructions (Siddall et al., 2003) had barely started. While we cannot rule out that the dust source became exhausted just before terminations, at least the inundation of the shelf must be playing a limited role in reducing the dust source. It is difficult to examine the phasing of sea level and dust fluxes during inception, because the sea level records are less detailed, and not well-synchronised to ice core data even at the last inception. However, we do note that the nssCa flux, at both the Dome $\mathrm{C}$ and the EPICA Dronning Maud Land (EDML) sites reduced by a factor of about 5 during the large Antarctic Isotopic Maximum (AIM) 8, at about $38 \mathrm{ka}$ (Fischer et al., 2007), while sea level likely varied only by the order of $20 \mathrm{~m}$ (Siddall et al., 2003), and therefore played only a small role. It therefore appears that the greatest part of the factorial changes in nssCa have to come from another source, although sea level/ continental shelf area changes can contribute, especially during periods when sea level changes between 80 and $150 \mathrm{~m}$, and probably only by a factor $2-3$.

\subsubsection{Changes in transport and lifetime against deposition}

The proportion of dust emitted from South America that arrives over the Antarctic continent is determined by how much is lost by deposition from the air mass during transport, which is determined by the ratio of the transport time to the residence time against wet and dry deposition (Hansson, 1994). The proportion retained should increase if either the transport speed increases, or the deposition lifetime increases.

Regarding the transport time, a number of lines of evidence suggest that it did not change very significantly, at least between the LGM and present. Firstly, it was expected that increased transport speed would lead to larger particles being carried to Antarctica; in fact the small change in particle size of the dust in the Dome C ice core between the Holocene and LGM is in the opposite direction, at face value suggesting lower speeds in the LGM (Lambert et al., 2008). Making assumptions about the transport path over Antarctica, the relatively constant ratio of nssCa flux at the EDML and Dome $C$ sites over the last glacial cycle can be interpreted as meaning that the ratio of transport time to residence time was relatively constant (within a factor 2) (Fischer et al., 2007). Finally, GCM modelling studies that incorporate atmospheric transport and deposition (Lunt and Valdes, 2001; Werner et al., 2002; Krinner and Genthon, 2003; Mahowald et al., 2006) predicted no significant change in concentration at Antarctic ice core sites unless source strengths were changed. This is in contrast to the results of a simple two-dimensional model (Yung et al., 1996) that would predict a 5 -fold increase in flux of dust to Antarctica due to a weakened hydrological cycle in the LGM. This discrepancy between different types of model suggests that more focus is needed on understanding the transport pathways and altitudes, to assess the relevance of wet deposition. However, taking all the empirical and modelling studies together, the factor of 5 seems to be an extreme upper limit to the likely importance of the lifetime 


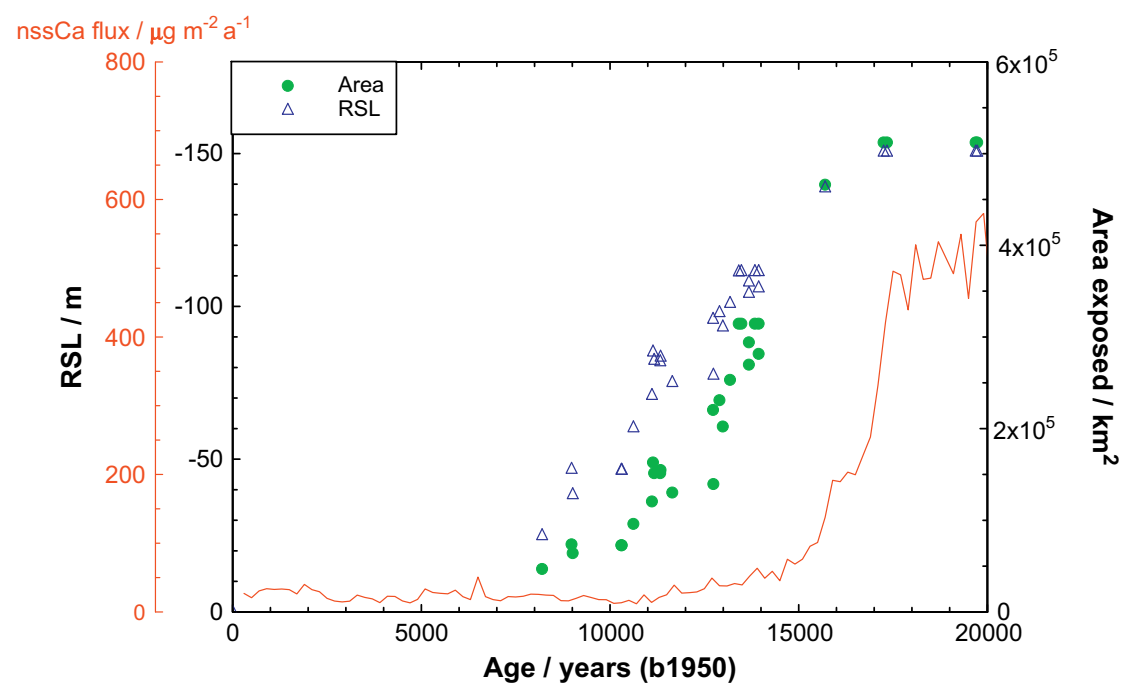

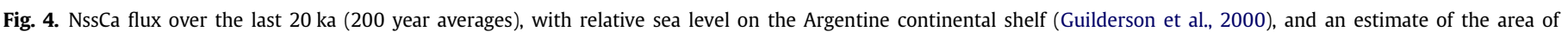
continental shelf (relative to present, south of $45^{\circ} \mathrm{S}$ ) exposed.

and transport effect together, with no change being also within the range of possibilities.

\subsubsection{Changes in South American climate}

Taking the above into account, we consider that most (factor 5-20 between LGM and present) of the changes seen in the nssCa flux profile have to be caused by changes in dust production in southern South America. Such changes might be the result of the growth of the Patagonian ice sheet, which should affect both the production of fine material, and the climate and hydrology of the region. Other factors would be the humidity of the climate, affecting the ability of vegetation to stabilise the surface, and the surface wind speed, potentially affecting uplift of dust in a highly non-linear way. Many of these factors are in fact closely related to the overall atmospheric circulation over southern South America, and in particular the strength and latitude range of the southern westerlies.

Unfortunately, there is conflicting evidence, both from palaeorecords (Markgraf et al., 1992; Moreno et al., 1999) and from modelling studies (Kim et al., 2003; Shin et al., 2003; Otto-Bliesner et al., 2006) about how the westerlies changed. Part of the discrepancy is due to the importance of correct specification of the boundary conditions (especially SSTs and sea ice), and part is due to the fact that the westerly wind band is relatively broad: simple statistics such as the latitude of maximum strength do not adequately describe the effect of the changes at particular locations.

To assess the possible effects of changing westerlies in South America, we have carried out a modelling study, using the Hadley Centre HadAM3 model with boundary conditions taken from the GLAMAP reconstruction (Paul and Schäfer-Neth, 2003). We have integrated the modelled surface winds over the ocean sector upwind of southern South America, from longitude $92^{\circ} \mathrm{W}$ to $69{ }^{\circ} \mathrm{W}$ (avoiding problems due to low model resolution relative to topography over the continent itself). In this model test (Fig. 5), we find a slight decrease in wind speed with LGM sea surface temperatures (compared to present) in summer, but a very significant increase during winter over a substantial latitude band at the south of South America. While we do not want to stretch the quantitative significance of this result, we note that, if the main dust production area was between 45 and $55^{\circ} \mathrm{S}$, and if the main production was in winter, then substantial changes in moisture input and in dust uplift might be expected. This is because entrainment is a highly non-linear process, featuring cubic increases in production for increases in wind speed above the entrainment threshold. We note that analyses in which a single annual statistic for wind speed was used would not have captured this change.

It is also possible that other thresholds can arise, in which nssCa does not show further changes beyond a certain stage of Antarctic warmth: this can for example represent a situation in which the main changes in wind speed occur south of the landmass, or (as in winter for the pre-industrial (Fig. 5)) where the latitudinal wind profile is rather flat, so that further latitudinal shifts do not provoke a change in wind speed at relevant latitudes.

Although we have highlighted the potential role of changes in wind, the inconclusive results of both data and models on the changes that occurred, even between the LGM and present, means

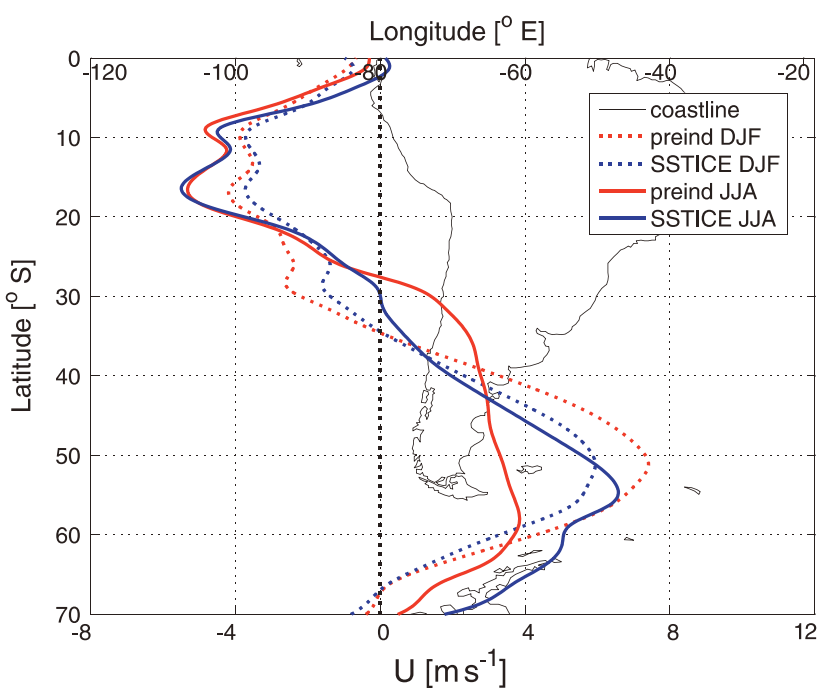

Fig. 5. Surface wind speed profile against latitude, averaged over grid boxes in the longitude sector from 268.125 to $290.625^{\circ}$ (91.875 ${ }^{\circ}$ to $69.375^{\circ} \mathrm{W}$ ), from the HadAM3 model using pre-industrial (PI) and LGM (SSTICE) boundary conditions, for winter (JJA) and summer (DJF) months, underlain with a map of South America. 
that we cannot confidently ascribe changes in dust source strength to winds. The supply of dust in Patagonia must have been affected by the strength, nature and location of glacial outwash as the Patagonian ice sheet waxed and waned (Sugden et al., 2009); aridity must certainly have changed, not only due to circulation changes but also due to the general cooling of the atmosphere. While we ascribe the main changes to conditions in South America, the exact cause and nature of those changes remains to be determined.

\subsubsection{Summary of terrestrial input}

In summary, we consider, with the present state of knowledge that it is likely that changes at the South American source played a very significant role in the observed changes in nssCa (of factor 20 ), but acknowledge that changes in exposed area may play a role ( $\sim$ factor 2 ), and that the role of changes in lifetime of dust in the atmosphere might contribute anything from a factor 1 (based on the more complex models) to an extreme estimate of factor 5.

Irrespective of the causes of change, we re-iterate that dust reaching Antarctica has passed over large tracts of the Southern Ocean, and it is believed that southern South America is also the main source of dust to most of the Southern Ocean. The nssCa flux profile can therefore be seen as a first order indicator of the input of dust, including Fe, to the Southern Ocean, and that it can therefore be used in modelling studies as a scaling for input for iron fertilisation (Kohler and Fischer, 2006). The scaling would need to be adjusted if the losses in transport were actually a large part of the cause of change between cold and warm periods. Realistic studies will also need to concern themselves with any changes in $\mathrm{Fe} / \mathrm{Ca}$ ratios in dust, in the solubility of the dust, and more exotic issues such as ligand availability (Parekh et al., 2008). However, as long as these issues are difficult to quantify, nssCa from Dome $\mathrm{C}$ provides a robust and well-resolved dataset of the first order changes.

In this regard, we have previously pointed out that nssCa dropped to near-interglacial low levels in many terminations rather early in the termination, and in particular at a time when $\mathrm{CO}_{2}$ had only risen by 20-30 ppmv from its glacial value (Röthlisberger et al., 2002b; Wolff et al., 2006). A similar situation applies at inceptions, with $\mathrm{CO}_{2}$ dropping in the absence of large changes in nssCa. This supports the similar observation that in some large AIM in the last glacial cycle, nssCa returns to almost interglacial values even though $\mathrm{CO}_{2}$ has an excursion of only around 20 ppmv (Röthlisberger et al., 2004). These observations allowed us to suggest on empirical grounds alone that fertilisation by dust (iron in particular) could not contribute more than 20 ppmv to the glacialinterglacial $\mathrm{CO}_{2}$ change, although its contribution could certainly be smaller (Parekh et al., 2008; Fischer et al., 2010).

As an additional point, we note that particularly low values of $\mathrm{CO}_{2}$, some 10 ppmv lower than those seen in other glacials, were observed in MIS 16 and 18, around 670 and 745 ka ago (Lüthi et al., 2008) (Fig. 6). The periods of especially low $\mathrm{CO}_{2}$ concentrations are accompanied by nssCa fluxes that are no different to those seen in other glacials. We can therefore deduce that additional Fe fertilisation was not the cause of the reduced $\mathrm{CO}_{2}$ in this interval.

\subsection{Marine aerosol}

As discussed in section 2 (because of preservation issues with $\mathrm{Cl}^{-}$) ssNa flux is the most reliable indicator of sea salt input; it shows higher values in glacial than interglacials by about a factor 2 (Fig. 1). The significance of sea salt fluxes, and their possible use as a sea ice indicator, has been discussed in several places (Wolff et al., 2003; Wolff et al., 2006; Fischer et al., 2007; Röthlisberger et al., 2008; Röthlisberger et al., 2010). We will not repeat the arguments

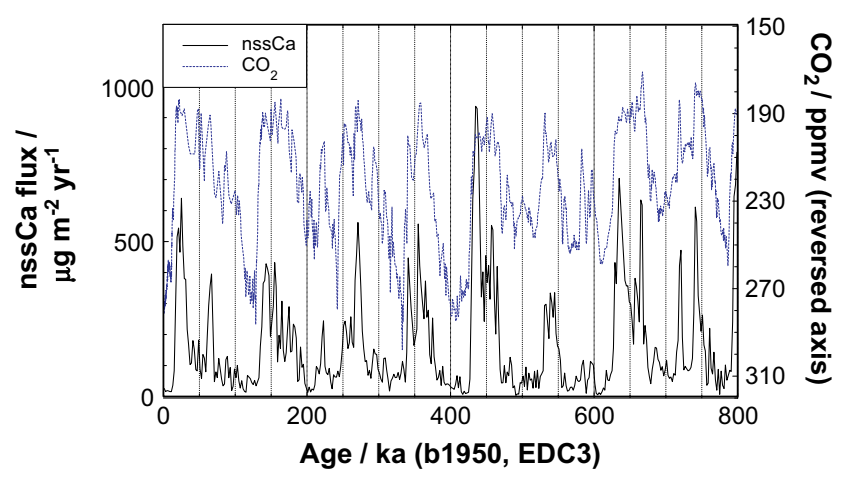

Fig. 6. NssCa flux and $\mathrm{CO}_{2}$ concentration over the last $800 \mathrm{ka}$.

in full here, but only summarise the present status of sea salt as a sea ice indicator.

The hypothesis that sea salt is positively related to features of sea ice relies on the idea that there is a significant source of sea salt aerosol on the surface of sea ice, and that this sea ice material reaches central Antarctica. The main identifier for such a source is the depletion of sulfate relative to sodium that is expected and observed in coastal aerosol and snow (Wagenbach et al., 1998; Rankin et al., 2002) and in frost flower samples. However, it has been difficult to demonstrate its occurrence in central Antarctica, because relative to its presence in sea salt, there is a large background of nssSO ${ }_{4}^{2-}$ that masks any depletion. However, in a detailed study of size resolved aerosol at Dome C, it has been shown clearly that sulfate-depleted aerosol contributes significantly to the sea salt input to that site (Jourdain et al., 2008), at least in winter when sea salt concentrations peak; this adds to evidence from aerosol measurements at Dome Fuji (Hara et al., 2004). Since no method other than fractionation of mirabilite on sea ice surfaces has been shown to produce aerosol depleted in sulfate, this appears to confirm that the sea ice surface is currently a major source of sea salt to central Antarctica - it is reasonable to assume that its importance (relative to the open water source) can only have been greater when sea ice was extended, and open water more distant, in glacial times.

It has also not been clear what aspect of sea ice extent the flux of sea salt to the ice sheet might represent. Frost flowers are related to new sea ice in open leads and polynyas, which led to the suggestion that sea salt was an indicator of ice production, and only secondarily (because the late summer sea ice extent around much of Antarctica is minimal) of extent. However, open leads do occur throughout the sea ice zone, so frost flower production may also be directly related to sea ice extent. Moreover a convincing case has recently been made that snow on sea ice, made saline by flooding and wicking of brine, might actually be the major source of sea salt aerosol, mobilised by sublimation of blowing snow (Yang et al., 2008). This requires further study, but since salty snow likely overlies the entire sea ice area, it opens the way to an assumption that the formation of sea salt aerosol depends on the ice extent (with a bias towards the maximum extent in spring) rather than just new production. Finally it has also been pointed out that with this ubiquitous source, the sensitivity of sea salt flux to sea ice extent will be highly non-linear, dropping off rapidly at large ice extents (Fischer et al., 2007; Röthlisberger et al., 2010). There is an urgent need to calibrate the proxy through modelling studies using different sources of sea salt, but meanwhile the available evidence seems to support the idea that sea salt can be used as a sea ice extent proxy, but with much reduced sensitivity (amounting to a threshold) at very large ice extents. We expect the proxy to be 
particularly suitable at extents lesser or slightly greater than today, i.e for different interglacials. It is therefore noteworthy that in the last interglacial, when the deuterium profile suggests that Antarctic temperature was considerably warmer (up to $4^{\circ} \mathrm{C}$ ) than today (Jouzel et al., 2007), the sea salt proxy suggests a simultaneous period of considerably reduced sea ice extent (the minimum for the last $800 \mathrm{ka}$ ) (Fig. 7) which would clearly be part of the feedbacks reinforcing the warmer temperatures.

\subsection{Biogenic sulfur}

Methanesulfonic acid is not used in this paper because it is modified post-depositionally, and does not represent the production of S compounds around Antarctica. We therefore present only the extended record of $\mathrm{nsSO}_{4}^{2-}$, now covering $800 \mathrm{ka}$. This confirms that this proxy remains remarkably constant over the entire period (within $+/-15 \%$, which is small considering the uncertainty in the snow accumulation rate used to calculate fluxes), with no apparent contrast between glacial and interglacial. This supports our previous interpretation that, at least in the sector of ocean producing DMS whose oxidation products reach Dome $\mathrm{C}$, the productivity of DMS-producing organisms changed little throughout the period, in contrast to previous assumptions (Legrand et al., 1991). As we have previously discussed (Wolff et al., 2006), this result means that ice cores provide no evidence for the operation, over glacial-interglacial cycles, of the biogenic feedbacks implied by the CLAW hypothesis (Charlson et al., 1987), in which the marine biogenic response to climate change would lead to a feedback through changes in aerosol concentration. We note that, if terrestrial sulfate (discussed in Section 3) was significant, then

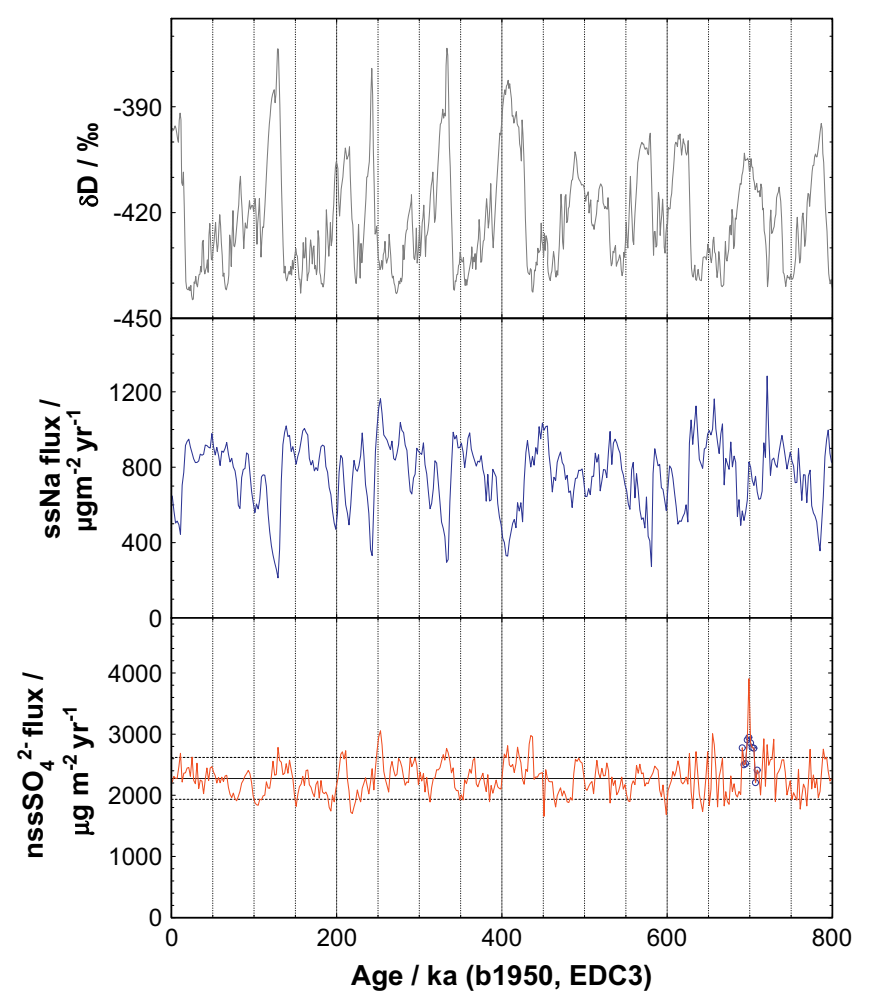

Fig. 7. SsNa and nssSO ${ }_{4}^{2-}$ over the last $800 \mathrm{ka}$, compared with deuterium. The bands around the nssSO ${ }_{4}^{2-}$ plot represent a mean $+/-15 \%$. The obvious outlier around $699 \mathrm{ka}$ comes from two samples that integrated $1.1 \mathrm{~m}$ of ice each. The blue dots show the data covering the same depth and time period obtained by averaging high resolution $(15 \mathrm{~cm})$ samples; this suggests that the outlier is an analytical artefact. glacial fluxes of DMS-derived sulfate would actually be lower than those in interglacials. The nssSO ${ }_{4}^{2-}$ record for the last glacial cycle is examined in more detail in another paper in this volume; ammonium is discussed in detail there as well (Kaufmann et al., 2010).

\subsection{Acidic gases: nitrate and chloride}

The first order control on nitrate concentrations in central Antarctic ice cores appears to be the dust content of the ice (represented by nssCa). At times of high nssCa concentration, nitrate seems to be at least partially protected (Röthlisberger et al., 2000b, 2002a) against loss processes that clearly occur during the Holocene and other warm periods (through a combination of sublimation and photolysis).The very strong congruence of $\mathrm{NO}_{3}^{-}$and nssCa concentrations previously reported in the last glacial cycle at Dome $\mathrm{C}$ (Röthlisberger et al., 2000b) and over several cycles at Vostok (Legrand et al., 1999) is clearly seen throughout the record shown in Fig. 2. Nonetheless there are several peaks (some denoted with arrows in the figure) where nitrate rises in the absence of any change in nssCa: these occur during interglacials and we discuss them now in more detail.

It is already known that, at times when nssCa is low, and $\mathrm{NO}_{3}^{-}$is poorly preserved, the next order influence on its concentration is the snow accumulation rate, with high accumulation rates leading to better preservation and higher concentrations (Röthlisberger et al., 2002a). We have followed previous work (Legrand et al., 1999) in plotting our nitrate concentrations against nssCa concentrations (using $2 \mathrm{ka}$ averages) in order to derive a best fit correction for the small amounts of Ca present in interglacial ice; the fit is calculated only for [nssCa] $>10 \mu \mathrm{g} \mathrm{kg}^{-1}$ and is $\left[\mathrm{NO}_{3}^{-}\right]=0.939^{*} \mathrm{nssCa}+7.51$ (all in $\mu \mathrm{g} \mathrm{kg}^{-1}$ ), with an $r^{2}$ of 0.79 . The $\mathrm{xsNO}_{3}^{-}$we then calculate (by subtracting $0.939^{*} \mathrm{nssCa}$ from the nitrate concentrations) is plotted only for interglacials with low dust content ( $\mathrm{Ca}<4 \mu \mathrm{g} \mathrm{kg}^{-1}, \delta \mathrm{D}>-410 \%$ ) in Fig. 8 along with the snow accumulation rate from the EDC3 age model; the accumulation rates were derived from the deuterium values, assuming a relationship between temperature and deuterium and between accumulation rate and temperature (Parrenin et al., 2007). The use of $\mathrm{xsNO}_{3}^{-}$rather than $\mathrm{NO}_{3}^{-}$in this plot makes an assumption that the amount of nitrate trapped with dust extends to the less dusty interglacial ice; however, the correction is rather small (on average less than $1 \mathrm{ug} \mathrm{kg}{ }^{-1}$ ), and the same plot using uncorrected $\mathrm{NO}_{3}^{-}$(not shown here) looks very similar.

Using the scaling we have chosen, it is obvious that $\mathrm{xsNO}_{3}^{-}$is extremely well-related to snow accumulation rate. We first observe that the small early Holocene accumulation rate increase (from 25 to $30 \mathrm{~kg} \mathrm{~m}^{-2} \mathrm{a}^{-1}$ ) is indeed accompanied by a small increase in $\mathrm{xsNO}_{3}^{-}$concentration. However, we are also matching very well onto the significantly higher accumulation rate of the last interglacial. If we assume that the EDC3 accumulation rates for the Holocene and last interglacial are relatively well-constrained then (making the slightly questionable assumption of linearity), we can use them to calibrate nitrate as an accumulation proxy. The nitrate values fit very well to the accumulation rates in MIS 7.5, 9 and 11, suggesting that there are no significant errors in those rates. They fall above the model accumulation rates in MIS 7.3, 13, 15 and 17. While this requires further investigation, it might suggest that the modelled accumulation rates there are too low. We must be cautious, because these are somewhat colder than most of the "calibration period", and we have not yet considered the effect of temperature on nitrate preservation; furthermore, the use of $\mathrm{XSNO}_{3}^{-}$as an accumulation indicator makes the implicit assumption that the nitrate source function is invariant (or at least plays no significant role in setting snow concentrations). It is noteworthy that, in tuning the EDC3 age scale, it was necessary to change the 


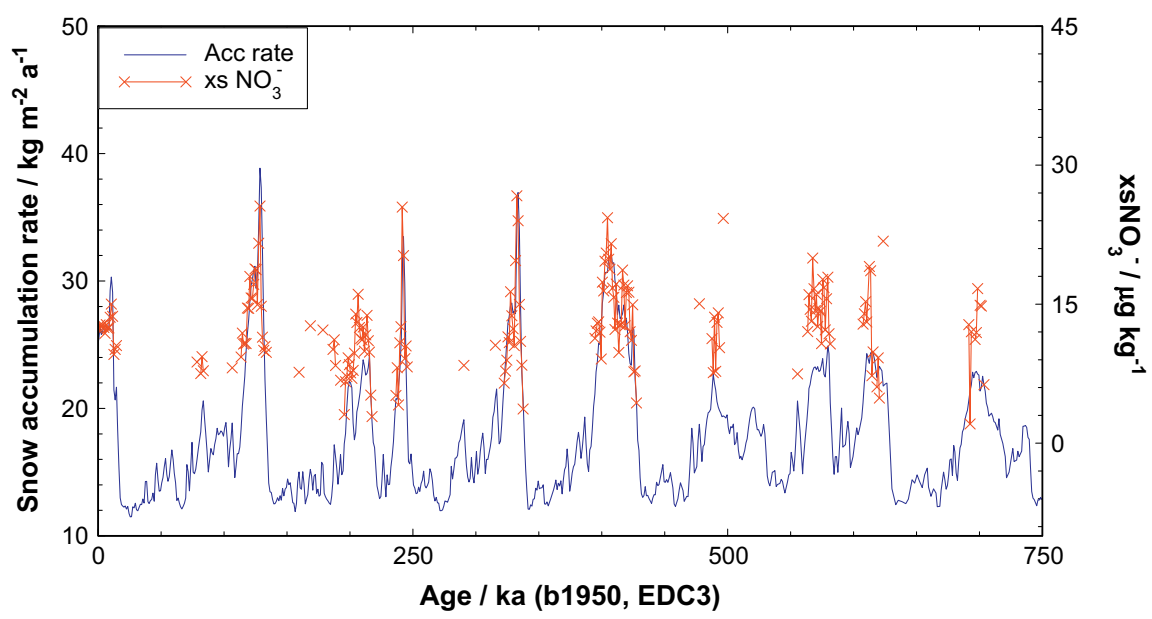

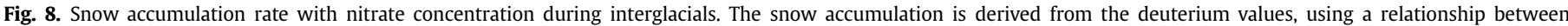

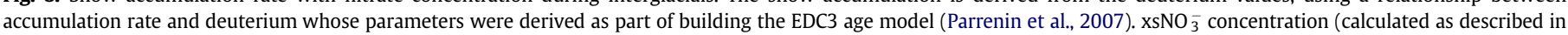
the text) is plotted only where nssCa is $<4 \mu \mathrm{g} \mathrm{kg}{ }^{-1}$ and $\delta \mathrm{D}>-410 \%$.

thinning function in MIS 14 and 15.1; estimates of the magnitude of the ice age-gas age depth difference suggested this as a superior option to changing the accumulation rate (Dreyfus et al., 2007). However the evidence for this was weak, and our evidence, although also rather tenuous, possibly suggests that an increased accumulation rate, at least in MIS15.1, might also be part of the solution to resolving the age scale.

Finally, it has previously been shown (again only over the last $45 \mathrm{ka}$ ), that the ratio of $\mathrm{Cl}^{-} / \mathrm{Na}$ is highly variable along a core (Röthlisberger et al., 2003). It can be both above and below the seawater ratio of 1.8 by weight, due to the reaction of $\mathrm{HNO}_{3}$ or $\mathrm{H}_{2} \mathrm{SO}_{4}$ with $\mathrm{NaCl}$, which produces gaseous $\mathrm{HCl}$, but depletes the aerosol in chloride, and a varying preservation of $\mathrm{HCl}$ in snow depending on parameters that again include snow accumulation rate. The ratio is shown in Fig. 9 over $800 \mathrm{ka}$. As found previously, the ratio reaches the seawater ratio only at times of very high dust concentration; it was previously proposed that at such times there is little atmospheric acidity to promote the reaction that creates $\mathrm{HCl}$. It was also found previously that the ratio was low during the Holocene, but increased sharply in the early Holocene when snow accumulation rate was slightly higher. This conclusion is confirmed by the extended dataset: the ratio soars to over 3 when the snow accumulation rate was at its highest in the last interglacial. It reaches above 1.8 in other warm interglacials, but remains low during cooler interglacials. Although further work is warranted (for example using multiple sites with different accumulation rates) we do not yet see a sufficiently simple relationship to try to derive a further quantitative proxy from the $\mathrm{Cl}^{-} / \mathrm{Na}$ ratio. However, it appears to be a useful and sensitive qualitative indicator: in the absence of high dust concentrations (i.e. during warm interglacials) snow accumulation rates higher than $30 \mathrm{~kg} \mathrm{~m}^{-2} \mathrm{a}^{-1}$ seem to be conducive to preservation of $\mathrm{Cl}^{-}$in Antarctic snow.

\section{Summary - new lessons from the $800 \mathrm{ka}$ of chemical data}

Huge amounts of chemical data from ice cores exist. However, it is more challenging to make environmental interpretation from them than it is for the iconic water isotope and trace gas records, because the short atmospheric lifetimes and multiple sources of some chemical species add complexity to their transfer functions. Nonetheless, the situation has greatly improved in recent years, due to a combination of measurements in the atmosphere and surface snow, modelling studies, and the rich nature of the long ice core datasets now available. As a result, strong (albeit somewhat tentative) conclusions about important aspects of the Earth system can now be drawn from ice core records, including here the $800 \mathrm{ka}$ EPICA Dome C dataset.

For terrestrial material (represented in this paper by nssCa), it is now clear that very major changes in the climatic conditions in southern South America over glacial-interglacial transitions must have occurred, while changes in atmospheric lifetime and continental area played a more limited role. It will however be a challenge to modellers to sufficiently constrain past changes in atmospheric circulation over South America to realistically capture the changes in dust production. In any case the different dust proxies in the ice core form an invaluable product for use in

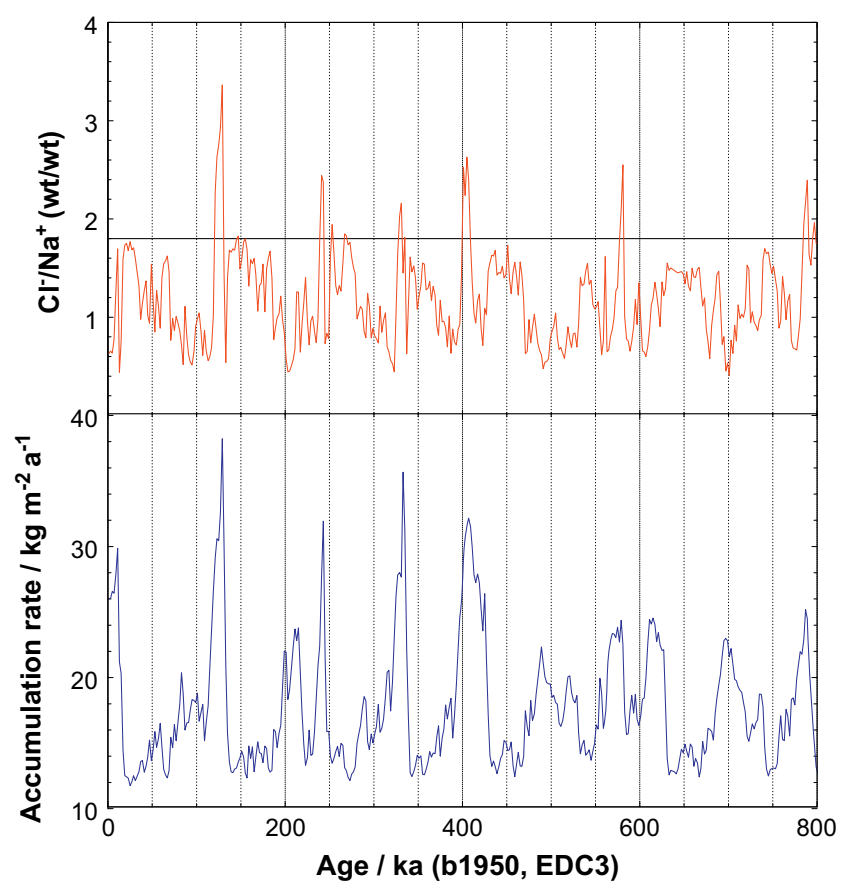

Fig. 9. The weight ratio of $\mathrm{Cl} / \mathrm{Na}$ for the Dome $\mathrm{C}$ ice core. The black horizontal line shows the seawater ratio of 1.8 . The snow accumulation rate deduced from deuterium is also shown. 
modelling the input of potentially-fertilising material to the Southern Ocean, and the temporal pattern of dust change strongly constrains the maximum extent and timing of iron fertilisation as a contributor to $\mathrm{CO}_{2}$ change.

Additional evidence has strengthened the idea that the sea ice surface is a major contributor to sea salt in central Antarctica, while new ideas about the nature of the source seem to point to ice extent as a primary control. However, it has also been recognised that the response falls off strongly at large ice extents, and therefore the proxy (which still requires a good model calibration) is most useful under moderate or interglacial conditions. In this respect, we have pointed out that an exceptionally low sea ice extent must have played an amplifying role in the unusually high temperatures of the last interglacial (Fischer et al., 2007).

Nss-sulfate flux is remarkably flat across the entire $800 \mathrm{ka}$ section, despite the huge climate changes taking place. This suggests a surprising constancy in marine biogenic production, although this conclusion has to be confined to particular areas of the ocean, and particular species (DMS producers).

While their concentrations in Dome $C$ ice are largely controlled by factors unrelated to source strength, it seems that both nitrate and chloride are exceptionally sensitive to changes in snow accumulation rate during interglacials. They thus provide a useful confirmation of derived accumulation rates based on assumptions about the relationship between snow accumulation rate and deuterium content, and they also suggest at least one period (MIS15.1) in which accumulation rates might need to be reconsidered.

While the information deduced above is diverse, when we add it to biogeochemical information from trace gas measurements, and climate data deduced from water isotopes, the package of synchronised temporal environmental information provided by ice cores gives an exceptional set of constraints for comprehensive models of the behaviour of the Earth system, that coincidentally are just now becoming available for palaeoclimate studies. Comparative data from other ice cores, data of higher resolution looking at shorter time periods, and focussed studies aimed at improving the quantitative interpretation of chemical proxies are now needed in order to make full use of the data already obtained.

\section{Acknowledgments}

This work is a contribution to the European Project for Ice Coring in Antarctica (EPICA), a joint European Science Foundation/European Commission (EC) scientific programme, funded by the EU (EPICA-MIS) and by national contributions from Belgium, Denmark, France, Germany, Italy, The Netherlands, Norway, Sweden, Switzerland and the UK. The main logistic support at Dome $C$ was provided by IPEV and PNRA.

\section{References}

Basile, I., Petit, J.R., Touron, S., Grousset, F.E., Barkov, N., 2001. Volcanic layers in Antarctic (Vostok) ice cores: source identification and atmospheric implications. Journal of Geophysical Research-Atmospheres 106 (D23), 31915-31931.

Bigler, M., Rothlisberger, R., Lambert, F., Stocker, T.F., Wagenbach, D., 2006. Aerosol deposited in East Antarctica over the last glacial cycle: detailed apportionment of continental and sea-salt contributions. Journal of Geophysical Research 111 (D8), D08205. doi:08210.01029/02005JD006469.

Bowen, H.J.M., 1979. Environmental Chemistry of the Elements. Academic Press, London, $333 \mathrm{pp}$.

Castellano, E., Becagli, S., Jouzel, J., Migliori, A., Severi, M., Steffensen, J.P., Traversi, R., Udisti, R., 2004. Volcanic eruption frequency over the last $45 \mathrm{ky}$ as recorded in Epica-Dome C ice core (East Antarctica) and its relationship with climatic changes. Global and Planetary Change 42 (1-4), 195-205.

Charlson, R.J., Lovelock, J.E., Andreae, M.O., Warren, S.G., 1987. Oceanic phytoplankton, atmospheric sulphur, cloud albedo and climate. Nature 326, 655-661.
Delmonte, B., Andersson, P.S., Hansson, M., Schoberg, H., Petit, J.R., Basile-Doelsch, I., Maggi, V., 2008. Aeolian dust in East Antarctica (EPICA-Dome C and Vostok): provenance during glacial ages over the last 800 kyr. Geophysical Research Letters 35 (7), L07703. doi:10.1029/2008GL033382.

Delmonte, B., Basile-Doelsch, I., Petit, J.R., Maggi, V., Revel-Rolland, M., Michard, A., Jagoutz, E., Grousset, F., 2004. Comparing the Epica and Vostok dust records during the last 220,000 years: stratigraphical correlation and provenance in glacial periods. Earth-Science Reviews 66 (1-2), 63-87.

Dreyfus, G.B., Parrenin, F., Lemieux-Dudon, B., Durand, G., Masson-Delmotte, V., Jouzel, J., Barnola, J.M., Panno, L., Spahni, R., Tisserand, A., Siegenthaler, U., Leuenberger, M., 2007. Anomalous flow below $2700 \mathrm{~m}$ in the EPICA Dome C ice core detected using $\delta^{18} \mathrm{O}$ of atmospheric oxygen measurements. Climate of the Past 3, 341-353.

EPICA Community Members, 2006. One-to-one hemispheric coupling of millennial polar climate variability during the last glacial. Nature 444, 195-198.

Fischer, H., Fundel, F., Ruth, U., Twarloh, B., Wegner, A., Udisti, R., Becagli, S., Castellano, E., Morganti, A., Severi, M., Wolff, E.W., Littot, G.C., Rothlisberger, R. Mulvaney, R., Hutterli, M.A., Kaufmann, P., Federer, U., Lambert, F., Bigler, M., Hansson, M., Jonsell, U., de Angelis, M., Gabrielli, P., Boutron, C., SiggaardAndersen, M.L., Steffensen, J.P., Barbante, C., Gaspari, V., Wagenbach, D., 2007. Reconstruction of millennial changes in transport, dust emission and regional differences in sea ice coverage using the deep EPICA ice cores from the Atlantic and Indian Ocean sector of Antarctica. Earth and Planetary Science Letters 260 (1-2), 340-354.

Fischer, H., Schmitt, J., Lüthi, D., Tschümi, T., Parekh, P., Joos, F., Stocker, T., Köhler, P., Völker, C., Gersonde, R., Barbante, C., Le Floch, M., Raynaud, D., Barnola, J.M., Chappellaz, J., Wolff, E., 2010. The role of Southern Ocean processes in orbital and millennial CO2 variations - a synthesis. Quaternary Science Reviews 29, 193-205.

Gabrielli, P., Plane, J.M.C., Boutron, C.F., Hong, S.M., Cozzi, G., Cescon, P., Ferrari, C., Crutzen, P.J., Petit, J.R., Lipenkov, V.Y., Barbante, C., 2006. A climatic control on the accretion of meteoric and super-chondritic iridium-platinum to the Antarctic ice cap. Earth and Planetary Science Letters 250 (3-4), 459-469.

Guilderson, T.P., Burckle, L.H., Hemming, S., Peltier, W.R., 2000. Late Pleistocene sea level variations derived from the Argentine Shelf. Geochemistry Geophysics Geosystems 1 (12) doi:10.1029/2000GC000098.

Hansson, M.E., 1994. The Renland ice core: a Northern Hemisphere record of aerosol composition over 120,000 years. Tellus 46B, 390-418.

Hara, K., Osada, K., Kido, M., Hayashi, M., Matsunaga, K., Iwasaka, Y., Yamanouchi, T., Hashida, G., Fukatsu, T., 2004. Chemistry of sea-salt particles and inorganic halogen species in Antarctic regions: compositional differences between coastal and inland stations. Journal of Geophysical Research 109, D20208. doi:10.1029/ $2004 J D 004713$.

Jourdain, B., Preunkert, S., Cerri, O., Castebrunet, H., Udisti, R., Legrand, M., 2008. Year-round record of size-segregated aerosol composition in central Antarctica (Concordia station): Implications for the degree of fractionation of sea-salt particles. Journal of Geophysical Research 113 (D14), D14308 doi:10.1029/ 2007JD009584.

Jouzel, J., Masson-Delmotte, V., Cattani, O., Dreyfus, G., Falourd, S., Hoffmann, G., Nouet, J., Barnola, J.M., Chappellaz, J., Fischer, H., Gallet, J.C., Johnsen, S. Leuenberger, M., Loulergue, L., Luethi, D., Oerter, H., Parrenin, F., Raisbeck, G., Raynaud, D., Schwander, J., Spahni, R., Souchez, R., Selmo, E., Schilt, A., Steffensen, J.P., Stenni, B., Stauffer, B., Stocker, T., Tison, J.-L., Werner, M. Wolff, E.W., 2007. Orbital and millennial Antarctic climate variability over the last 800,000 years. Science 317, 793-796.

Kaufmann, P., Fundel, F., Fischer, H., Bigler, M., Ruth, U., Udisti, R., Hansson, M., De Angelis, M., Barbante, C., Wolff, E.W., Hutterli, M., Wagenbach, D., 2010. Ammonium and non-sea-salt sulphate in the EPICA ice cores as indicators of biological activity in the Southern Ocean. Quaternary Science Reviews 29, 313-323.

Kaufmann, P.R., Federer, U., Hutterli, M.A., Bigler, M., Schüpbach, S., Ruth, U., Schmitt, J., Stocker, T.F., 2008. An improved continuous flow analysis (CFA) system for high-resolution field measurements on ice cores. Environmental Science \& Technology 42, 8044-8050.

Kim, S.J., Flato, G.M., Boer, G.J., 2003. A coupled climate model simulation of the last glacial maximum, Part 2: approach to equilibrium. Climate Dynamics 20 (6), 635-661.

Kohler, P., Fischer, H., 2006. Simulating low frequency changes in atmospheric $\mathrm{CO}_{2}$ during the last 740,000 years. Climate of the Past 2, 57-78.

Krinner, G., Genthon, C., 2003. Tropospheric transport of continental tracers towards Antarctica under varying climatic conditions. Tellus Series B-Chemical and Physical Meteorology 55 (1), 54-70.

Lambert, F., Delmonte, B., Petit, J.R., Bigler, M., Kaufmann, P.R., Hutterli, M.A Stocker, T.F., Ruth, U., Steffensen, J.P., Maggi, V., 2008. Dust-climate couplings over the past 800,000 years from the EPICA Dome C ice core. Nature 452 616-619.

Legrand, M., Feniet-Saigne, C., Saltzman, E.S., Germain, C., Barkov, N.I., Petrov, V.N 1991. Ice-core record of oceanic emissions of dimethylsulphide during the last climate cycle. Nature 350, 144-146.

Legrand, M., Léopold, A., Dominé, F., 1996. Acidic gases $\left(\mathrm{HCl}, \mathrm{HF}, \mathrm{HNO}_{3}, \mathrm{HCOOH}\right.$ and $\mathrm{CH}_{3} \mathrm{COOH}$ ): a review of ice core data and some preliminary discussions on their air-snow relationships. In: Wolff, E.W., Bales, R.C. (Eds.), Chemical Exchange Between the Atmosphere and Polar Snow. Springer Verlag, Berlin, pp. 19-43.

Legrand, M., Mayewski, P., 1997. Glaciochemistry of polar ice cores: a review. Reviews of Geophysics 35 (3), 219-243. 
Legrand, M., Wolff, E.W., Wagenbach, D., 1999. Antarctic aerosol and snowfall chemistry: implications for deep Antarctic ice core chemistry. Annals of Glaciology 29, 66-72.

Legrand, M.R., Delmas, R.J., 1988. Soluble impurities in four Antarctic ice cores over the last 30,000 years. Annals of Glaciology 10, 116-120.

Legrand, M.R., Lorius, C., Barkov, N.I., Petrov, V.N., 1988. Vostok (Antarctica) ice core: atmospheric chemistry changes over the last climatic cycle (160,000 years). Atmospheric Environment 22 (2), 317-331.

Lisiecki, L.E., Raymo, M.E., 2005. A Pliocene-Pleistocene stack of 57 globally distributed Benthic delta O-18 records. Paleoceanography 20 (1), PA1003. doi:10.1029/2004PA001071.

Littot, G.C., Mulvaney, R., Rothlisberger, R., Udisti, R., Wolff, E.W., Castellano, E., de Angelis, M. Hansson, M. Sommer, S., Steffensen, J.P. 2002. Comparison of analytical methods used for measuring major ions in the EPICA Dome $C$ (Antarctica) ice core. Annals of Glaciology 35, 299-305.

Loulergue, L., Schilt, A., Spahni, R., Masson-Delmotte, V., Blunier, T., Lemieux, B. Barnola, J.M., Raynaud, D., Stocker, T.F., Chappellaz, J., 2008. Orbital and millennial-scale features of atmospheric $\mathrm{CH}_{4}$ over the last 800,000 years. Nature 453, 383-386

Lunt, D.J., Valdes, PJ., 2001. Dust transport to Dome C, Antarctica, at the Last Glacial Maximum and present day. Geophysical Research Letters 28 (2), 295-298.

Lüthi, D., Le Floch, M., Stocker, T.F., Bereiter, B., Blunier, T., Barnola, J.M., Siegenthaler, U., Raynaud, D., Jouzel, J., 2008. High-resolution carbon dioxide concentration record 650,000-800,000 years before present. Nature 453, 379-382.

Mahowald, N.M., Muhs, D.R., Levis, S., Rasch, P.J., Yoshioka, M., Zender, C.S., Luo, C., 2006. Change in atmospheric mineral aerosols in response to climate: Last glacial period, preindustrial, modern, and doubled carbon dioxide climates. Journal of Geophysical Research 111 (D10), D10202. doi:10.1029/2005JD006653.

Markgraf, V., Dodson, J.R., Kershaw, A.P., McGlone, M.S., Nicholls, N., 1992. Evolution of late Pleistocene and Holocene climates in the circum-south Pacific land areas. Climate Dynamics 6 (3), 193-211.

Moreno, P.I., Lowell, T.V., Jacobson, G.L., Denton, G.H., 1999. Abrupt vegetation and climate changes during the last glacial maximum and last termination in the Chilean Lake District: A case study from Canal de la Puntilla (41 degrees s). Geografiska Annaler Series a-Physical Geography 81A (2), 285-311.

Otto-Bliesner, B.L., Brady, E.C., Clauzet, G., Tomas, R., Levis, S., Kothavala, Z., 2006 Last Glacial maximum and Holocene climate in CCSM3. Journal of Climate 19 (11), 2526-2544.

Parekh, P., Joos, F., Muller, S.A., 2008. A modeling assessment of the interplay between aeolian iron fluxes and iron-binding ligands in controlling carbon dioxide fluctuations during Antarctic warm events. Paleoceanography 23 (4) doi:10.1029/2007PA001531.

Parrenin, F., Barnola, J.M., Beer, J., Blunier, T., Castellano, E., Chappellaz, J., Dreyfus, G., Fischer, H., Fujita, S., Jouzel, J., Kawamura, K., Lemieux, B., Loulergue, L., Masson-Delmotte, V., Narcisi, B., Petit, J.R., Raisbeck, G., Raynaud, D., Ruth, U., Schwander, J., Severi, M., Spahni, R., Steffensen, J.P. Svensson, A., Udisti, R., Waelbroeck, C., Wolff, E.W., 2007. The EDC3 chronology for the EPICA Dome $C$ ice core. Climate of the Past 3, 485-497.

Paul, A., Schäfer-Neth, C., 2003. Gridded Global LGM SST and Salinity Reconstruction. IGBP PAGES/World Data Center for Paleoclimatology. Boulder Data Contribution Series 2003-046. NOAA/NGDC Paleoclimatology Program, Boulder, CO, USA.

Petit, J.R., Jouzel, J., Raynaud, D., Barkov, N.I., Barnola, J.M., Basile, I., Bender, M., Chappellaz, J., Davis, M., Delaygue, G., Delmotte, M., Kotlyakov, V.M Legrand, M., Lipenkov, V.Y., Lorius, C., Pepin, L., Ritz, C., Saltzman, E. Stievenard, M., 1999. Climate and atmospheric history of the past 420,000 years from the Vostok ice core, Antarctica. Nature 399, 429-436.

Raisbeck, G.M., Yiou, F., Cattani, O., Jouzel, J., 2006. ${ }^{10}$ Be evidence for the MatuyamaBrunhes geomagnetic reversal in the EPICA Dome C ice core. Nature 444, 82-84.

Rankin, A.M., Wolff, E.W., Martin, S., 2002. Frost flowers - implications for tropospheric chemistry and ice core interpretation. Journal of Geophysical Research 107 (D23), 4683.

Röthlisberger, R., Bigler, M., Hutterli, M., Sommer, S., Stauffer, B., Junghans, H.G. Wagenbach, D., 2000a. Technique for continuous high-resolution analysis of trace substances in firn and ice cores. Environmental Science and Technology 34, 338-342.

Röthlisberger, R., Hutterli, M.A., Sommer, S., Wolff, E.W., Mulvaney, R., 2000b. Factors controlling nitrate in ice cores: evidence from the Dome C deep ice core. Journal of Geophysical Research 105 (D16), 20565-20572.

Röthlisberger, R., Bigler, M., Wolff, E.W., Joos, F., Monnin, E., Hutterli, M., 2004. Ice core evidence for the extent of past atmospheric $\mathrm{CO}_{2}$ change due to iron fertilisation. Geophysical Research Letters 31, L16207. doi:10.1029/2004GL020338.

Röthlisberger, R., Crosta, X., Abram, N.J., Armand, L., Wolff, E.W., 2010. Potential and limitations of marine and ice core sea ice proxies: an example from the Indian Ocean sector. Quaternary Science Reviews 29, 296-302.

Röthlisberger, R., Hutterli, M.A., Wolff, E.W., Mulvaney, R., Fischer, H., Bigler, M. Goto-Azuma, K., Hansson, M.E., Ruth, U., Siggaard-Andersen, M.-L Steffensen, J.P., 2002a. Nitrate in Greenland and Antarctic ice cores: a detailed description of post-depositional processes. Annals of Glaciology 35, 209-216.

Röthlisberger, R., Mudelsee, M., Lambert, F., Bigler, M., Sime, L., Wolff, E.W., MassonDelmotte, V., De Angelis, M., Fischer, H., Hansson, M., Udisti, R., 2008. The southern hemisphere at glacial terminations: insights from the Dome $\mathrm{C}$ ice core. Climate of the Past 4, 345-356.
Röthlisberger, R., Mulvaney, R., Wolff, E.W., Hutterli, M., Bigler, M., de Angelis, M., Hansson, M., Steffensen, J.P., Udisti, R., 2003. Limited dechlorination of sea salt aerosols during the last glacial period - evidence from the European Project for Ice Coring in Antarctica (EPICA) Dome C ice core. Journal of Geophysical Research 108 (D16), 4526. doi:10.1029/2003JD003604.

Röthlisberger, R., Mulvaney, R., Wolff, E.W., Hutterli, M., Bigler, M., Sommer, S. Jouzel, J., 2002b. Dust and sea salt variability in central East Antarctica (Dome C) over the last 45 kyrs and its implications for southern high-latitude climate. Geophysical Research Letters 29 (20), 1963. doi:10.1029/2002GL015186.

Ruth, U., Barbante, C., Bigler, M., Delmonte, B., Fischer, H., Gabrielli, P., Gaspari, V., Kaufmann, P., Lambert, F., Maggi, V., Marino, F., Petit, J.R., Steffensen, J.P., Udisti, R., Wagenbach, D., Wegner, A., Wolff, E.W., 2008. Proxies and measurement techniques for mineral dust in Antarctic ice cores. Environmental Science \& Technology 42 (15), 5675-5681.

Savarino, J., Kaiser, J., Morin, S., Sigman, D., Thiemens, M.H., 2007. Nitrogen and oxygen isotopic constraints on the origin of atmospheric nitrate in coastal Antarctica. Atmospheric Chemistry and Physics 7, 1925-1945.

Shin, S.I., Liu, Z., Otto-Bliesner, B., Brady, E.C., Kutzbach, J.E., Harrison, S.P., 2003. A simulation of the last glacial maximum climate using the NCAR-CCSM. Climate Dynamics 20 (2-3), 127-151.

Siddall, M., Rohling, E.J., Almogi-Labin, A., Hemleben, C., Meischner, D., Schmelzer, I., Smeed, D.A., 2003. Sea-level fluctuations during the last glacial cycle. Nature 423 (6942), 853-858.

Sugden, D.E., McCulloch, R.D., Bory, A.J.M, Hein, A.S., 2009. Influence of patagonian glaciers on Antarctic dust deposition during the last glacial period. Nature Geoscience 2(4), 281-285.

Traversi, R., Becagli, S., Castellano, E., Migliori, A., Severi, M., Udisti, R., 2002. Highresolution fast ion chromatography (FIC) measurements of chloride, nitrate and sulphate along the EPICA Dome C ice core. Annals of Glaciology 35, 291-298.

Udisti, R. Becagli, S, Benassai, S, de Angelis, M. Hansson, M.E, Jouzel, J. Schwander, J., Steffensen, J.P., Traversi, R., Wolff, E.W., 2005. Sensitivity of chemical species to climatic changes in the last 45 kyrs as revealed by high resolution Dome C (Antarctica) ice core analysis. Annals of Glaciology 39, 457-466.

Wagenbach, D., Ducroz, F., Mulvaney, R., Keck, L., Minikin, A., Legrand, M., Hall, J.S., Wolff, E.W., 1998. Seasalt aerosol in coastal Antarctic regions. Journal of Geophysical Research 103 (D9), 10961-10974.

Wagnon, P., Delmas, R.J., Legrand, M., 1999. Loss of volatile acid species from upper firn layers at Vostok, Antarctica. Journal of Geophysical Research 104 (D3), 3423-3431.

Watanabe, O., Jouzel, J., Johnsen, S., Parrenin, F., Shoji, H., Yoshida, N., 2003a. Homogeneous climate variability across East Antarctica over the past three glacial cycles. Nature 422, 509-512.

Watanabe, O., Kamiyama, K., Motoyama, H., Fujii, Y., Igarashi, M., Furukawa, T., GotoAzuma, K., Saito, T., Kanamori, S., Kanamori, N., Yoshida, N., Uemura, R., 2003b. General tendencies of stable isotopes and major chemical constituents of the Dome Fuji deep ice core. Memoirs of National Institute of Polar Research. 57 $1-24$, (special issue)

Weller, R., Traufetter, F., Fischer, H., Oerter, H., Piel, C., Miller, H., 2004. Post depositional losses of methane sulfonate, nitrate, and chloride at the EPICA deepdrilling site in Dronning Maud Land, Antarctica. Journal of Geophysical Research 109 (7) doi:10.1029/2003JD004189.

Werner, M., Tegen, I., Harrison, S.P., Kohfeld, K.E., Prentice, I.C., Balkanski, Y., Rodhe, H., Roelandt, C., 2002. Seasonal and interannual variability of the mineral dust cycle under present and glacial climate conditions. Journal of Geophysical Research 107 (D24), 4744. doi:10.1029/2001JD002365.

Winckler, G., Fischer, H., 2006. 30,000 years of cosmic dust in Antarctic ice. Science 313 (5786), 491

Wolff, E.W., Fischer, H., Fundel, F., Ruth, U., Twarloh, B., Littot, G.C., Mulvaney, R., Rothlisberger, R., de Angelis, M., Boutron, C.F., Hansson, M., Jonsell, U., Hutterli, M.A., Bigler, M., Lambert, F., Kaufmann, P., Stauffer, B., Stocker, T.F., Steffensen, J.P., Siggaard-Andersen, M.L., Udisti, R., Becagli, S., Castellano, E. Severi, M., Wagenbach, D., Barbante, C., Gabrielli, P., Gaspari, V., 2006. Southern Ocean sea-ice extent, productivity and iron flux over the past eight glacial cycles. Nature 440, 491-496.

Wolff, E.W., Fischer, H., Fundel, F., Ruth, U., Twarloh, B., Littot, G.C., Mulvaney, R., Rothlisberger, R., de Angelis, M., Boutron, C.F., Hansson, M., Jonsell, U., Hutterli, M.A., Bigler, M., Lambert, F., Kaufmann, P., Stauffer, B., Stocker, T.F., Steffensen, J.P., Siggaard-Andersen, M.L., Udisti, R., Becagli, S., Castellano, E. Severi, M., Wagenbach, D., Barbante, C., Gabrielli, P., Gaspari, V., 2007. Correction to Southern Ocean sea-ice extent, productivity and iron flux over the past eight glacial cycles. Nature 449, 748

Wolff, E.W., Jones, A.E., Bauguitte, S.J.-B., Salmon, R.A., 2008. The interpretation of spikes and trends in concentration of nitrate in polar ice cores, based on evidence from snow and atmospheric measurements. Atmospheric Chemistry and Physics 8, 5627-5634.

Wolff, E.W., Rankin, A.M., Rothlisberger, R., 2003. An ice core indicator of Antarctic sea ice production? Geophysical Research Letters 30 (22), 2158.

Yang, X., Pyle, J.A., Cox, R.A., 2008. Sea salt aerosol production and bromine release: role of snow on sea ice. Geophysical Research Letters 35 (16), L16815 doi:10.1029/2008GL034536.

Yung, Y.L., Lee, T., Wang, C.-H., Shieh, Y.-T., 1996. Dust: a diagnostic of the hydrologic cycle during the last glacial maximum. Science 271, 962-963. 